\title{
Impact of Work Stress during COVID-19 Epidemic on Job Satisfaction and Job Performance among Nurses in Critical Care Units, United Arab Emirates 2020
}

\author{
Rennie Joshua*, Fouad Chehab, Reni David, Nezar Ahmed Salim \\ Nursing Department, Dubai Hospital, Dubai Health Authority, United Arab Emirates.
}

\begin{abstract}
How to cite this paper: Rennie Joshua, Fouad Chehab, Reni David, Nezar Ahmed Salim. (2021) Impact of Work Stress during COVID-19 Epidemic on Job Satisfaction and Job Performance among Nurses in Critical Care Units, United Arab Emirates 2020. International Journal of Clinical and Experimental Medicine Research, 5(2), 225-231.

DOI: 10.26855/ijcemr.2021.04.018
\end{abstract}

Received: March 15, 2021

Accepted: April 12, 2021

Published: April 28, 2021

*Corresponding author: Rennie Joshua, Nursing Department, Dubai Hospital, Dubai Health Authority, United Arab Emirates.

Email: renniepty@gmail.com

\begin{abstract}
Background: The health of health caregivers is the prime concern for any organization. The emotional and physical stability of nurses is very important for safe and effective patient care. The accelerating changes in the health care setup often leads to stress and this affects the job performance and job satisfaction among nurses placing patient care at risk. In December 2019, the health care system faced challenges by the new emerging virus-SARS CoV-2. Facing large scale of critically ill patient with COVID-19 has led to great health concern for all the medical staffs both physically and psychologically. As the work environment undergoes accelerating changes and instability, stress is often been experienced by individuals and organizations. Objectives: The main goal of this study was to assess the impact of work stress during COVID-19 epidemic on Job Satisfaction and Job Performance among nurses in Critical Care Units in one of the government hospitals in Dubai, United Arab Emirates. Methodology: This study was carried out in one of the government hospital in Dubai, Dubai Health Authority (DHA), United Arab Emirates between the period July 2020 till December 2020. A convenience sample was recruited for the purposes of this study. The sample of this study consisted of 240 participants who worked in critical care units during the pandemic. Data were analyzed using Statistical Package for the Social Sciences (SPSS) Version 23. Result: Results reveal that there was major impact of stress on job satisfaction and job performance. The empirical findings indicate statistical significance of job satisfaction and designations and staffs working long hours, as direct patient care providers are less satisfied. The stress level during the pandemic was very high among the staffs working in critical care units. Conclusion and Recommendation: Work place stress has a lot of impact on job satisfaction and job performance. 21\%-36.8\% staffs had high to very high level of stress during the pandemic crisis. The main factor leading to stress was the workload.
\end{abstract}

\section{Keywords}

Job stress, performance, satisfaction, workload, pandemic, long working hours 


\section{Introduction}

The health of health care givers is the prime concern for any organization. The emotional and physical stability of nurses is very important for safe and effective patient care. The accelerating changes in the health care set up often leads to stress and this affects the job performance and job satisfaction among nurses placing patient care at risk. Both job satisfaction and employee performance are important factors for any organization. Organizations invest many resources like time and money on recruitment process, selection and training and development of employees. If any employee feels that his basic needs are not addressed by the organization his performance is affected [1]. An ICU nurse has to work with increased workload, which includes fast decision-making, working with sophisticated technology and needs prompt action in response to alteration in patient's condition. ICU nurses experience more occupational stress than staffs working in general wards. The need for critical care beds is increasing [2].

In December 2019, the health care system faced challenges by the new emerging virus-SARS CoV-2. Facing large scale of critically ill patient with COVID-19 has led to great health concern for all the medical staffs both physically and psychologically. Findings of a quantitative study revealed that frontline health care workers dealing with COVID-19 patients are at risk of developing mental health problems like anxiety, depression, insomnia and stress [3].

Countries like Italy had reported severe shortage of health care professionals to meet up the demand during the pandemic, even retired professionals and new graduates were called to meet up the workload. The long recovery time of patients from pneumonia had contributed to overcrowding of patients in intensive care units. As the work environment undergoes accelerating changes and instability, stress has often been experienced by individuals and organizations. Stress is not confided to a group of people or related to a particular job, it is been experienced by many people in the organizations. Nurses are the backbone of health care organizations. With the pandemic of Covid-19, it is quite evident that it is quite challenging for any health care organization to deal with the situation without adequate nursing staff and the existing staffs definitely faces work-related stress due to inadequate staffing and increased workload. Nurses spend the entire shift on their feet working long hours dealing with fatigue and infectious patients. Employees who face job burnout and stress on a wider scale are expected to perform less when compared to employees who face less stress in the workplace [1]. Stress and burnout not only impacts the performance of the employee, but it also affects employees' commitment and job satisfaction [4]. Job performance of an employee is also a critical factor for the organizations success. The institutions performance is actually the result of employees' effort and commitment [5]. Today the driving force for any organizations excellence is employee satisfaction. Systems are in place to focus and measure employee's satisfaction level so that an improvement action can be taken [6].

By March 8, 2020, around 80,815 cases of infections were reported in China with Novel Corona virus infection, 3,073 deaths, and more than 3,000 health care professionals were reported as being tested positive for the virus. Nurses are the most vulnerable group among the health care professionals to contact with the patient, as they are the direct care providers [7]. One of the important indicator of Quality and Risk Management is Occupational health and safety issues. It is important to ensure safety of all employees working in an organization and it should not be affected by work place environment. It is also a social responsibility and an important element of managerial development processes. This is one of the core elements for sustainable development and success of health care system. The ultimate goal is to improve patient care from healthy workforce. The effect of stress on job performance and job satisfaction is evident in literature [8].

\section{Methodology}

\subsection{Setting, Design, Sample}

This study was carried out in one of the government health sectors in Dubai, Dubai Health Authority (DHA), United Arab Emirates between the periods July 2020 till December 2020. A convenience sample was recruited for the purposes of this study. There was no limit on the sample size. All nurses working with critically ill patients was approached and asked to participate in the study.

\subsection{Inclusion and exclusion criteria}

The participants who were included in the study had directly contacted with COVID-19 patients and were working in critical care units. On the other hand, staff working in wards with stable COVID patients were excluded from 
the current study.

\subsection{Instrument and data collection}

A standardized tool was adopted for the purposes of this study. The tool consisted of 5 dimensions: Workload, Competencies and Physical Conditions, Work place Health and Safety Concerns, Job Performance and Job Satisfaction with demographical data sheet. A formal permission was obtained from the author of the tool.

\subsection{Study Procedure}

Tools were distributed online by using Google forms in order to lessen the contact time with COVID-patients. The survey will take 20-30 minutes from participants.

\subsection{Planned data analysis}

Data were checked for completeness and accuracy prior to data coding and entry. Descriptive statistics including percentages, means, and standard deviations were used to describe the sample and to summarize survey scores. Independent - $t$ tests was used to determine differences in mean scores $\mathrm{p}<0.05$ was considered statistically significant. Data were analyzed using Statistical Package for the Social Sciences (SPSS) Version 23.

\subsection{Ethical approval}

The study was reviewed by Dubai Scientific Research Committee (DSRC). Institutional Review Board (IRB) approval was obtained in order to start data collection. The questionnaire and consent form were given to the participants who meet the inclusion criteria. An information sheet was attached with the questionnaire explaining to them the purpose of the study. Participants were assured that the confidentiality and privacy of the answers will be maintained. No names, phone numbers, and identification were required as a part of data.

\subsection{Result part}

Table 1. Participants Demographical Data

\begin{tabular}{cccc}
\hline Variables & Group & Frequency & Percentage \\
\hline Designation & Assistant Nurse & 9 & $4.7 \%$ \\
& Staff Nurse 1 & 2 & $1 \%$ \\
& SN2 & 153 & $79.3 \%$ \\
& SN3 & 21 & $10.9 \%$ \\
Unit & SSN & 4 & $2.1 \%$ \\
& CN & 4 & $2.1 \%$ \\
& MICU & 28 & $14.5 \%$ \\
& SICU & 27 & $14.0 \%$ \\
& L6W & 88 & $45.6 \%$ \\
Nationality & L3E & 32 & $16.6 \%$ \\
& L6E & 18 & $9.3 \%$ \\
& Indian & 100 & $51.8 \%$ \\
& Filipino & 88 & $45.6 \%$ \\
& Jordanian & 1 & $.5 \%$ \\
Actual Working Hours & Pakistani & 2 & $1.0 \%$ \\
& Other & 2 & $1.0 \%$ \\
Compensation & 7-8 hrs. & 73 & $37.8 \%$ \\
& 8-10 hrs. & 120 & $62.2 \%$ \\
& Yes & 31 & $16.1 \%$ \\
& No & 162 & $83.9 \%$ \\
\hline
\end{tabular}


The sample consisted of 193 participants; the majority were SN2 (79.3\%) and working in L6W (45.6\%). In terms of nationality, 100 (51.8\%) and 88 (45.6\%) Indian and Filipino, respectively. The study revealed that majority of the participants worked 8-10 hrs. per shift (62.2\%) and (37.8\%) 7-8hrs. Regarding compensation, 83.9\% received no compensation for the extra hours of work and $16.1 \%$ received compensation (Table 1).

As Reflected by GAMMA test, Job Satisfaction and Job Performance was highly effected by stress as the result was highly statistically significant since $\mathrm{p}=0.001$ (Table 2).

Table 2. Association factors between Stress and Job performance and Satisfaction by using GAMMA test

\begin{tabular}{|c|c|c|c|c|c|}
\hline \multirow[b]{2}{*}{ Variable } & \multirow[b]{2}{*}{ Group } & \multicolumn{3}{|c|}{ Job Performance } & \multirow[t]{2}{*}{ P-Value } \\
\hline & & Excellent & Acceptable & Poor & \\
\hline \multirow{5}{*}{ Stress } & Very Low & $88.2 \%$ & $5.9 \%$ & $5.9 \%$ & \multirow{5}{*}{0.000} \\
\hline & Low & $67.3 \%$ & $26.5 \%$ & $6.1 \%$ & \\
\hline & Neutral & $83.5 \%$ & $10.3 \%$ & $6.2 \%$ & \\
\hline & High & $75.3 \%$ & $18.5 \%$ & $6.2 \%$ & \\
\hline & Very high & $57.7 \%$ & $20.4 \%$ & $21.8 \%$ & \\
\hline & \multicolumn{5}{|c|}{ Job Satisfaction } \\
\hline \multirow[t]{3}{*}{ Variable } & Group & Satisfied & Neutral & Dissatisfied & \multirow{6}{*}{0.000} \\
\hline & Very Low & $88.2 \%$ & $5.9 \%$ & $5.9 \%$ & \\
\hline & Low & $81.6 \%$ & $12.2 \%$ & $6.1 \%$ & \\
\hline \multirow[t]{3}{*}{ Stress } & Neutral & $86.6 \%$ & $11.3 \%$ & $2.1 \%$ & \\
\hline & High & $86.2 \%$ & $11.2 \%$ & $2.5 \%$ & \\
\hline & Very high & $58.5 \%$ & $21.8 \%$ & $19.7 \%$ & \\
\hline
\end{tabular}

As ANOVA test showed that job performance was not significant with both designation and workplace $\mathrm{p}>0.05$. On the other hand, job satisfaction was not significant with workplace but was statistically significant with designation $\mathrm{p}<0.05$ (Table 3 ).

Table 3. One-Way Analysis of Variance (ANOVA) of Job performance, Job satisfaction with designation and unit

\begin{tabular}{|c|c|c|c|c|c|c|c|}
\hline Variables & Group & & Sum of Squares & df & Mean Square & $\mathbf{F}$ & Sig. \\
\hline \multirow[t]{3}{*}{ Job Performance } & Designation & Between Groups & 5.395 & 4 & 1.349 & 1.728 & 0.145 \\
\hline & & Within Groups & 146.729 & 188 & 0.780 & & \\
\hline & & Total & 152.124 & 192 & & & \\
\hline \multirow[t]{3}{*}{ Job Satisfaction } & Designation & Between Groups & 10.226 & 4 & 2.557 & 4.258 & 0.003 \\
\hline & & Within Groups & 112.882 & 188 & 0.600 & & \\
\hline & & Total & 123.109 & 192 & & & \\
\hline \multirow[t]{3}{*}{ Job Performance } & Unit & Between Groups & 3.836 & 4 & 0.959 & 1.216 & 0.306 \\
\hline & & Within Groups & 148.289 & 188 & 0.789 & & \\
\hline & & Total & 152.124 & 192 & & & \\
\hline \multirow[t]{3}{*}{ Job Satisfaction } & Unit & Between Groups & 0.639 & 4 & 0.160 & 0.245 & 0.912 \\
\hline & & Within Groups & 122.470 & 188 & 0.651 & & \\
\hline & & Total & 123.109 & 192 & & & \\
\hline
\end{tabular}

Table 4 shows that job performance was not affected by working hours and compensation, while job satisfaction was affected by working hours $\mathrm{p}<0.05$ but not by compensation $\mathrm{p}>0.05$. 
Table 4. Independent t-test result comparing job performance, job satisfaction with working hours and compensation

\begin{tabular}{|c|c|c|c|c|c|c|c|c|c|c|}
\hline \multirow[t]{2}{*}{ Variables } & & \multirow[t]{2}{*}{ Group } & \multirow[t]{2}{*}{$\mathbf{N}$} & \multirow[t]{2}{*}{ Mean/S.D } & \multirow[t]{2}{*}{$\begin{array}{l}\text { Mean dif- } \\
\text { ferences }\end{array}$} & \multirow[t]{2}{*}{$\mathbf{t}$} & \multirow[t]{2}{*}{ df } & \multicolumn{2}{|c|}{$\begin{array}{l}\text { 95\% Confidence } \\
\text { Interval of the Dif- } \\
\text { ference }\end{array}$} & \multirow[t]{2}{*}{ Sig. } \\
\hline & & & & & & & & Upper & Lower & \\
\hline \multirow{2}{*}{$\begin{array}{l}\text { Job Perfor- } \\
\text { mance }\end{array}$} & \multirow{2}{*}{$\begin{array}{l}\text { Working } \\
\text { hours }\end{array}$} & $\begin{array}{c}\text { 7-8 } \\
\text { hours }\end{array}$ & 73 & 2.18/.933 & 0.178 & 1.35 & 191 & 0.438 & -0.082 & \multirow{2}{*}{0.153} \\
\hline & & $\begin{array}{c}\text { 8-10 } \\
\text { hours }\end{array}$ & 120 & $2.00 / .860$ & 0.178 & 1.32 & 142.59 & 0.444 & -0.088 & \\
\hline \multirow{2}{*}{$\begin{array}{l}\text { Job Satisfac- } \\
\text { tion }\end{array}$} & \multirow{2}{*}{$\begin{array}{l}\text { Working } \\
\text { hours }\end{array}$} & $\begin{array}{c}\text { 7-8 } \\
\text { hours }\end{array}$ & 73 & 1.63/.677 & -0.053 & -0.44 & 191 & 0.182 & -0.288 & \multirow{2}{*}{0.013} \\
\hline & & $\begin{array}{l}8-10 \\
\text { hours }\end{array}$ & 120 & $1.68 / .869$ & -0.053 & -0.47 & 179.56 & 0.168 & -0.275 & \\
\hline \multirow{2}{*}{$\begin{array}{l}\text { Job Perfor- } \\
\text { mance }\end{array}$} & \multirow{2}{*}{ Compensation } & Yes & 31 & $1.84 / .638$ & -0.272 & -1.5 & 191 & 0.070 & -0.615 & \multirow{2}{*}{0.076} \\
\hline & & No & 162 & 2.11/.926 & -0.272 & -2.0 & 57.35 & -0.001 & -0.544 & \\
\hline \multirow{2}{*}{$\begin{array}{l}\text { Job Satisfac- } \\
\text { tion }\end{array}$} & \multirow[t]{2}{*}{ Compensation } & Yes & 31 & $1.52 / .626$ & -1.75 & -1.1 & 191 & 0.134 & -0.485 & \multirow{2}{*}{0.102} \\
\hline & & No & 162 & $1.69 / .829$ & -1.75 & -1.3 & 52.42 & 0.085 & -0.436 & \\
\hline
\end{tabular}

Figure 1 below shows that the most important factor leading to stress during the Pandemic COVID-19 is workload, followed by competency to work with infected cases and finally the workplace and safety concern.

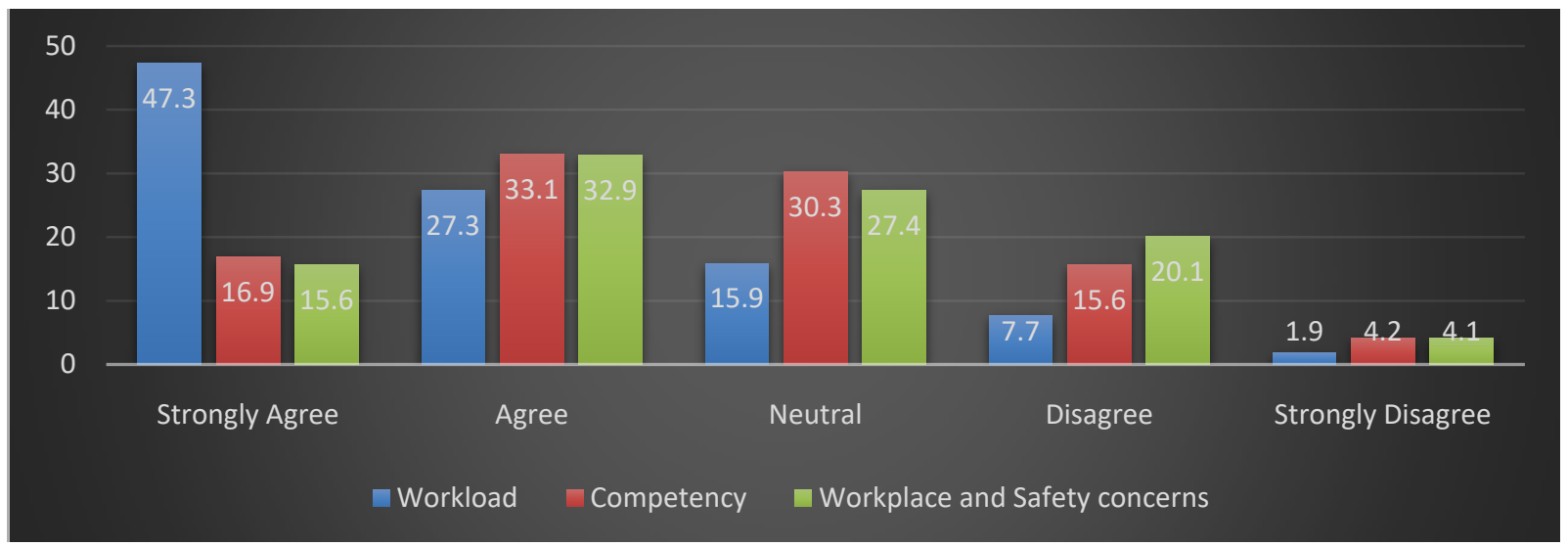

Figure 1. Staff perception about Factors leading to stress Workload/Competency/Workplace and Safety Concerns.

The figure below (Figure 2) represents that vast majority of staffs 36.8\% had very high level of stress during the pandemic crisis. Only $4.4 \%$ staff had very low stress.

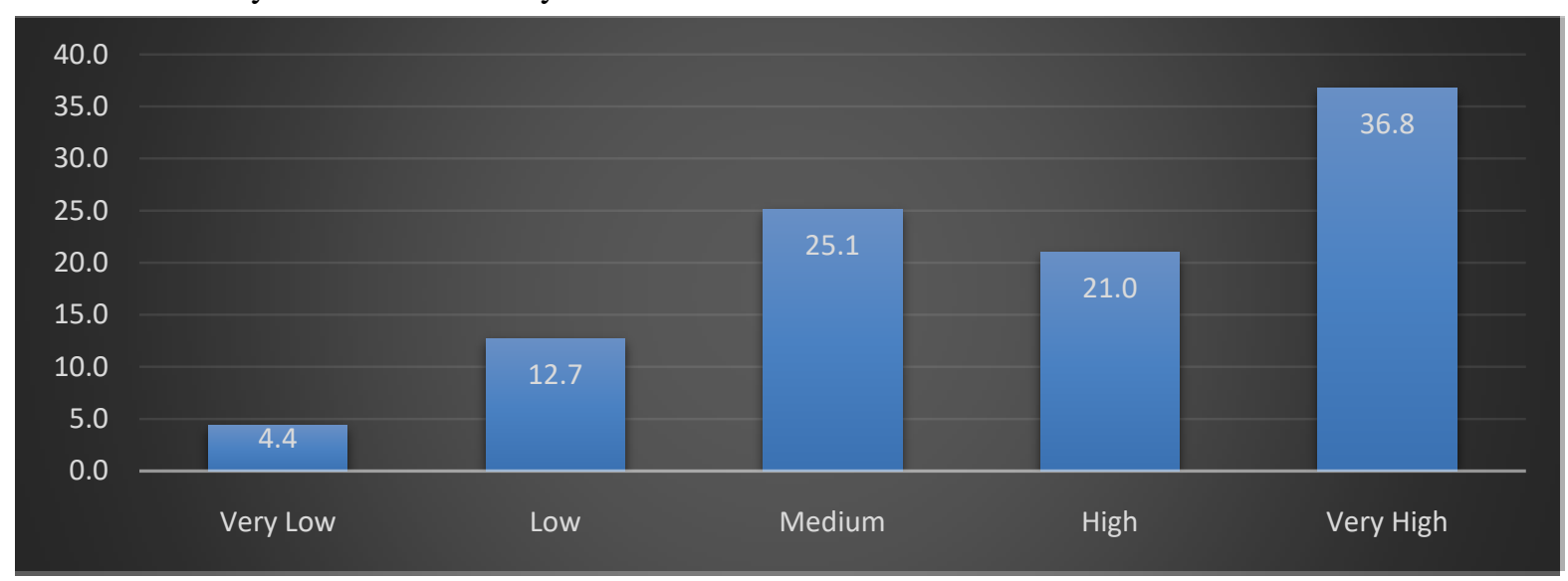

Figure 2. Overall stress during COVID-19 Pandemic Crisis. 


\section{Discussion}

The main goal of the current study was to assess Impact of Work Stress during COVID-19 epidemic on Job Satisfaction and Job Performance among nurses in Critical Care Units. To best of our knowledge, this is the first study conducted in United Arab Emirates especially in critical care units. The result of the study suggested that stress could affect staff performance and their satisfaction. Poor performance among nurses could influence patient's safety. Increasing workload is caused by enormous work to complete in minimum time span. High workload could drive employee with stress. Work stress is caused by several factors, which is highlighted in this study.

Our study concurs with the study conducted in 2012 by Chandhok and Tyagi [5]. They found that the employees who are stressed are likely to perform low and show less commitment due to the psychological pressure that is initiated due to various undesirable events. Similar findings was ruled out in a study [9], where they found that job stress experienced in the work environment is a critical factor to determine the performance of an individual. Alike findings was revealed in a study done among primary school teachers in Malaysia where job performance was influenced by the level of happiness and job satisfaction that an individual has [10].

In our study, job performance was not affected neither by the unit they work nor by the designation, whereas job satisfaction was affected by designation. The workload during the pandemic was more on staff nurses who are the direct patient care provider due to the increased number of critically ill patients and staffs from all other areas were pulled in critical care units to meet up the huge demand. Health care workers are more prone to stress due to the changing environment [11]. In the same way in 2019, a study carried out by Joshua R. [12], aimed to assess psychological hazards among nurses working in different units and had controversial results. The work pressure was more in critical care units and cardiology units compared to other units and stress and depression was more among nurses working in critical care units. The association of stress and depression with designation was insignificant [12]. The difference in the result can be due to the pandemic crisis.

People who are satisfied with the length of their working hours are more satisfied [13]. A Systematic Review was study done by Banakhar, 2017 [14], which found that long working hours nurses experience more fatigue, and 9 out of 12 studies revealed that nurses with 12-hour shifts are more dissatisfied when compared to nurses working in 8 hours shift. After wearing the full set of protective clothing, long working hours for nurses working bedside can cause physical and mental exhaustion leading to burnout [15].

The findings of the present study are consistent with other studies, which found that nurses with long working hours had lower level of job satisfaction. Nurses working as direct patient care providers had 8 hours shift but were unable to be released from work on time due to the workload. Controversy, one recent study found that there were significant and positive correlations between working hours and occupational stress $(\mathrm{p}<0.01)$ and significant correlation between working hours and job satisfaction [16].

In every profession occupational stress exists, however, nursing profession appears to experience more level of stress due to the work nature. Stress if not managed well can lead to dissatisfaction, health problems, absenteeism, high turnover and decreased productivity. Dagger, Molla and Belachew [17] in 2016 published in their study that the main reasons of stress among nurses was due to dealing with dying patients, uncertainty regarding the treatment plan of the patient and excessive workload. In a study done in Iran, 78.4\% nurses responded that their job is stressful and the reasons of stress were excessive workload, shift work, salary, workplace discrimination and policies [18]. In our study, workload was the main reason of stress among the nurses.

WHO declared COVID-19 as pandemic on March 12, 2020. The mental health of health care professionals was severely challenged. The American Psychiatric Nurses Association notes that COVID 19 pandemic have imposed fear, exhaustion, isolation and emotional trauma and this ongoing stress affects the mental health of nurses [19]. A study conducted by Bennaoui et al, 2020, found that the stress among health care professionals was very high related to characteristics of the pandemic, depletion of PPE, transfer to the new area, lack of information, lack of critical care beds, shortage of drugs, ventilators, change in social and family life and lack of training [20].

\section{Conclusion and Recommendation}

The aim of the study was to assess the impact of stress on job satisfaction and job performance during the pandemic. Workplace stress has impact on job satisfaction and is critically important for high-level performance. Workload is a major factor leading to stress and should be managed well. The current study concluded that health care workers responding to pandemic outbreak as front liners are more prone to stress and anxiety. Avoiding situations that can affect the mental health of health care workers is difficult, but we can minimize the negative effect of such pandemics by doing regular mental health assessment, offering support services, therapeutic therapy, provision 
of adequate protective supplies, offering treatment options and rendering full organizational support to the staffs working during the crisis

\section{Ethics Approval and Consent to Participate}

Ethical approval was obtained from Dubai scientific research ethics committee in Dubai Health Authority (DHA) prior to data collection. Ref No. DSREC-07/2020_11

\section{Acknowledgements}

The research team wants to thank Ms. Avon Jane Strahle (Assistant Director of Nursing, Dubai Hospital, and U.A.E) for her directions and guidance in formulating the research tool.

\section{References}

[1] Ahmad, H., Zarina I., Faridah I., Rima M. A., Natasha, K., and Normazwin, I. (2012). Workplace stress and behavior studies of other space: Commercial Complex. Procedia - Social \& behavioral Sciences, 36, pp. 752-769.

[2] Adhikari, N. K., Fowler, R. A., Bhagwanjee, S., \& Rubenfeld, Gordon, D. (2010). Critical care and the global burden of critical illness in adults. The Lancet, 376(9749), 1339-1346. doi:10.1016/S0140-6736(10)60446-1.

[3] Liu, Q., Luo, D., Haase, J. E., Guo, Q., Wang, X. Q., Liu, S., . . Yang, B. X. (2020). The experiences of health-care providers during the COVID-19 crisis in china: A qualitative study. The Lancet Global Health. doi:10.1016/S2214-109X(20)30204-7.

[4] Arshadi, N. and Damiri, H. (2013). The relationship of job stress with turnover intention and job performance: Moderating role of OBSE, Procedia - Social and Behavioral Sciences, 84, pp.706-710.

[5] Chandhok, A. and Tyagi, A. (2012), Impact of Job Stress on Employee’s Performance of Sales Department-A Comparative Study of LIC and Bajaj Allianz Life Insurance Company Ltd in the Selected Cities of Haryana. International Journal of Languages, Education and SocialSciences, 13(1), 7-17.

[6] Aziri, B. (2011). Job satisfaction: A literature review. Management Research and Practice, 3(4), 77-86.

[7] Huang, L., Lin, G., Tang, L., Yu, L., \& Zhou, Z. (2020). Special attention to nurses’ protection during the COVID-19 epidemic. Critical Care (London, England), 24(1), 120. doi:10.1186/s13054-020-2841.

[8] Bashir, U., \& Ramay, M. I. (2010). Impact of Stress on Employees Job Performance: A Study on Banking Sector of Pakistan. International Journal of Marketing Studies, Vol. 2, No. 1, 2, May 2010, pp. 122-126

[9] Justice Agyei Ampofo, Dr. Théophile Bindeouè Nassè, Dr. Lirasse Akouwerabou, 1U D S, T G 2U E, \& W G 3T S U B F. The effects of stress on performance of workers in ghana health service in wa municipal.

[10] Din Pian, T. A., Eam, L. H., and Abdullah, H. B. (2019). Impact of Happiness on Job Performance: The Case of Primary School Teachers in Malaysia. Business Perspective Review, 1(1), 43-52.

[11] Al-Aameri, A. S. and Al-Fawzan, N. M. (2005). Nurses strategies for coping with job stress. Saudi Medical Journal, 19(4), 366-371.

[12] Joshua, R. (2019). Psychosocial hazards among nurses. International journal of nursing research and practice. EISSN 2350-1324; Vol. 6 No. 1. DOI No. 10.15509/IJNRP.2019.6.1.367.

[13] Wanger, S. (2017). What makes employees satisfied with their working time? The role of working hours, time-sovereignty and working conditions for working time and job satisfaction No. 20/2017). Nürnberg: Institut für Arbeitsmarkt- und Berufsforschung (IAB). Retrieved from https://www.econstor.eu/handle/10419/172884.

[14] Banakhar, M. (2017). The impact of 12-hour shifts on nurses' health, wellbeing, and job satisfaction: A systematic review. Journal of Nursing Education and Practice, 7(11), 69. doi:10.5430/jnep.v7n11p69.

[15] Liu, Y. and Aungsuroch, Y. (2019). Work stress, perceived social support, self-efficacy and burnout among Chinese registered nurses. Journal of Nursing Management, 27(7), 1445-1453. doi:10.1111/jonm.12828.

[16] Nithyajothi, G. (2019). The impact of job stress, workload and long working hours on the job satisfaction of government doctors at tamil nadu. I-Manager’s Journal on Management, 14(1), 25. doi:10.26634/jmgt.14.1.15207.

[17] Dagget, T., Molla, A., and Belachew, T. (2016). Job related stress among nurses working in Jimma Zone public hospitals, South West Ethiopia: a cross sectional study. BMC Nurs., 15, 39(2016). https://doi.org/10.1186/s12912-016-0158-2.

[18] Kakemam, E., Raeissi, P., Raoofi, S., Soltani, A., Sokhanvar, M., Visentin, D. C., et al. (2019). Occupational stress and associated risk factors among nurses: A cross-sectional study. Null, 55(2-3), 237-249. doi:10.1080/10376178.2019.1647791.

[19] American Psychiatric Nurses Association (APNA). (2020). Managing stress \& self-care during COVID-19: Information for nurses. https://www.apna.org/i4a/pages/index.cfm?

[20] Bennaoui, F., Ei Idrissi Slitine, N., Maoulainine, F. M. R. (2020). Health professional stress during COVID-19 pandemic. Arch Psychiatr Ment Health. 2020; 4: 070-072. 